\title{
The Trace Elements Concentrations Dynamics in the Soil Landscapes of the Southern Russia
}

\author{
Vladimir Dyachenko*, Irina Matasova, Olga Ponomareva \\ Novorossiysk Polytechnic Institute (branch) of the Kuban State University of Technology, Novorossiysk, 353900, Krasnodar, Russia \\ *Corresponding Author: v-v-d@mail.ru
}

Copyright (C) 2014 Horizon Research Publishing All rights reserved.

\begin{abstract}
The article is addressed to the analysis of the results of the chemical elements monitoring in the soil landscapes of the Southern Russian Federation. The studies have been carrying out for over 30 years allowing repeatedly test the soils of different regions and generate the database with more than 9000 samples. The study findings show the increase of chemical elements concentration in the soils as a result of both - the global pollution and specific technology generated objects impact.
\end{abstract}

Keywords Soils, Trace elements, Landscapes, Pollution, Clark

\section{Introduction}

The results of soil-geochemical and landscape-geochemical studies show the global change of concentrations and chemical elements ratio in the environment and foreground the issues of assessment and monitoring of geochemical soils. But it is difficult to give a reasonable estimate of a degree of geochemical transformation and role of anthropogenic factor, supposed, from the beginning of the industrial age, because the first reliable information based on the results of soil sampling in the 40-50s of A.P. Vinogradov [1]. The situation in the regions is more difficult, because the geochemical studies became a regular fixture in the 70-80s, and the imperfection of applied methods of soil analysis does not allow estimating objectively the intensity and consistent patterns of their ecological and geochemical transformation, as well as the actual pollution rate of different landscapes.

In this behalf the South of Russia was "lucky" because the active landscape-geochemical investigations have been carrying out here since the mid of 70's in which the authors of the article participated in his student years. As a result, maps, atlases, database (more than 8000 sampling points), characterizing the distribution of chemical elements in geological systems of the Southern Russia (soils, rocks, plants) were created.

\section{Materials and Methods}

The chemical element concentrations dynamics in the soils of different landscapes in the Krasnodar region, North Ossetia, Rostov region was examined for determination of the scale and intensity of landscapes contamination in the South of Russia. The soils of these and other areas of the Southern Russia were uniformly examining in the regional landscape-geochemical survey from 1980 to 2012. The main examining object was the upper soil horizon $\mathrm{A}$, to a depth of $15-20 \mathrm{~cm}$, which is subject to be most polluted. The common database includes more than 9000 soil samples analyzed by spectral analysis on the content of 20-25 trace elements. It is very important that the preserved samples of soil of $80 \mathrm{~s}$ which are necessary for re-analysis to elimination of the potential impact on the results of the comparison of "laboratory drift". All results of laboratory studies were statistically analyzed and presented in the percent by mass or $\%$ and the standard error of mean was shown in the most important cases.

\section{Results}

\subsection{The Analysis of the Concentration Change in Soils of Various Landscapes of the South of Russia}

The change of chemical elements concentrations in natural and technogenic landscapes is methodologically correct to consider it separately. As if it is generally a result of natural processes and global pollution in biogenic landscapes, then the leading role in technogenic landscapes is played by the form of natural resources, pollution control and the other factors. However, the groups of elements with concentration dynamics in soils of natural and anthropogenic landscape is the same are seemed in all regions. For example, the concentration of $\mathrm{Pb}, \mathrm{Ni}, \mathrm{Mn}, \mathrm{Cu}, \mathrm{Co}, \mathrm{Cr}$ (the number of examining elements is determined by the analytical works of the 80s) was increased in the soils of natural and technogenic landscapes in Krasnodar region for 12-15 years (more than 3,000 samples were analyzed). Moreover, $\mathrm{Pb}, \mathrm{Cu}, \mathrm{Cr}$ were increasingly accumulated in the natural landscapes, and $\mathrm{Ni}$, 
Mn and Co were accumulated in technogenic landscapes (Table 1).

The content of Mo was eminently decreased in the soils of the region but the content of $\mathrm{Zn}, \mathrm{Ti}, \mathrm{Ga}$ and $\mathrm{Ba}$ was decreased incidentally. The analysis of trace elements dynamics in certain landscapes allows evaluating the process features in details. For example, the content of $\mathrm{Pb}$ was increased in $1,1-$ 2,2 times in the soils of 27 landscapes and in soils of natural landscapes were more intensive. The increasing of the content of $\mathrm{Cu}, \mathrm{Mn}$ and $\mathrm{Cr}$ is more visible in the soils of biogenic landscapes but among the anthropogenic landscapes it is visible in the soils of vine groves, gardens and pastures. The content of $\mathrm{Ni}$, was otherwise increased in $1,1-1,8$ times $\mathrm{n}$ the soils of all technogenic landscapes but was decreased in the soils of several biogenic landscapes.

The vine groves, gardens and pastures are actively selected among the landscapes. Moreover, the pastures are included formally in this list because they are in agricultural rotation with permanent crops and a biocenosis is lightly differ from a degraded steppe pasture few years after their grubbing. However the geochemistry of soils of 15-20 more years is defined by the introduced fertilizers and chemicals. Therefore, similarity of dynamics of microcells in soils with gardens and vineyards is inherited and is not bound to a cattle pasture.

The same group of the elements was allocated in the soils of landscapes of Volgodonsk region of Rostov region, and their concentrations for the last 12 years between approbations have been increased in these soils of all studied landscapes (Table 2).

This group includes $\mathrm{Pb}, \mathrm{Ni}, \mathrm{Ag}, \mathrm{Mo}, \mathrm{V}, \mathrm{Cr}$ and $\mathrm{Ga}$. In soils of agricultural landscapes the maintenance of the most biofilic elements $-\mathrm{P}$ considerably decreased, $\mathrm{Mn}$ and is less considerable $\mathrm{Ti}, \mathrm{Zn}$ and VA.

The analysis of the chemical elements concentration dynamics in soils of the bottom Don testifies to preservation of a tendency of accumulation of the majority of microcells (Table 3).

There was an increase in concentration in soils practically all metals and $\mathrm{Cr}, \mathrm{Zn}, \mathrm{Ni}$ and $\mathrm{Mn}$ is especially considerable.

The assessment of the microcells dynamics is carried out and in North Ossetia. In the mid-sixties, distribution of a wide range of chemical elements in soils and rocks from 82 holes (about 500 tests) E.V.Rubilin [2] was studied here. The most particular conclusions can be drawn on dynamics for $\mathrm{Cu}, \mathrm{Zn}, \mathrm{Pb}, \mathrm{Mo}, \mathrm{Ba}, \mathrm{Ni}, \mathrm{Mn}, \mathrm{V}$ and $\mathrm{Cr}$ as their concentration were defined not only in all tests of soils, but also rocks that gives the chance to exclude laboratory mistakes. For comparison the landscape of the broad-leaved woods with brown soils and as average concentration of chemical elements in soils of the North Caucasus and North Ossetia as a whole that is quite proved as in its territory all North Caucasian soils (Table 4) meet practically is used.

The analysis of these data testifies that from the middle of the 60th years concentration of all elements except $\mathrm{Mn}$ increased: $\mathrm{Ni}$ - by 2-2,8 times, Mo - twice, $\mathrm{V}-$ by 1,3-2,5 times, $\mathrm{Cu}$ and $\mathrm{Cr}$ - by 1,7-1,9 times, $\mathrm{Zn}$ - by 1,3-2,7 times. Comparison of concentration of $\mathrm{Ag}, \mathrm{W}, \mathrm{Co}, \mathrm{Ga}, \mathrm{Ge}, \mathrm{Sr}, \mathrm{Zr}$, Be does not allow to estimate their dynamics quantitatively in view of weak sensitivity of the analysis and low interest of detection in the sixties. However it is apparent that their concentration as considerably increased. As a whole intensity of increase in concentration of microcells in soils of this region is much higher in view of more long-lived period of monitoring, existence of developed fields of polymetals and influence of two large iron and steel works "Electrozinc" ( $\mathrm{Zn}, \mathrm{Cu}, \mathrm{Pb}, \mathrm{Ag}, \mathrm{Cd})$ and "Pobedit" (W, Mo, $\mathrm{Sn})$, located on the suburb of Vladikavkaz.

Studying of chemical composition of glaciers testifies to a tendency of increase of concentration of heavy metals in various components of landscapes of the Caucasus also. According to A.V.Yevseyev [4], in ice layers formed at the end of the nineteenth century, the maintenance of $\mathrm{Cu}, \mathrm{Pb}, \mathrm{Cd}$ is twice lower than the modern.

Thus, results of regional geoecological monitoring various landscapes of the South of Russia testify to the considerable change of maintenance of many chemical elements for the last decades and, first of all, to their essential increase. It is characteristic that in each region increase of concentration concerns the majority of chemical elements from considered, but their list and dynamics differ, owing to a various landscape and geochemical situation and technogenic loading. In pollution zones intensity of accumulation is higher and is characteristic for wider range of microcells. However, the role and global processes of aerogenic pollution that was repeatedly noted by results of studying of chemical composition of wood, peat bogs and world glaciers is great. Especially actively this process is shown in soils.

The soil, being on crossing of intra landscape migratory streams and possessing a pronounced cationic absorbing capacity, intensively accumulates and strongly holds positively the charged ions. According to some information $[5,6]$ metals very sluggishly are removed from the soil at a lixiviation, an erosion, consumption by plants and the period of natural semi-removal can make hundreds and thousands years $(\mathrm{Pb}$ - from 740 to 5900 years, $\mathrm{Cu}-$ from 310 to $1500, \mathrm{Zn}$ - from 70 to 510 years, etc.). Therefore their continuous receipt, even in trace amounts, leads to essential accumulation. It explains and more the fissile increase of contents of metals in soils of natural landscapes. They differ intensive biogeochemical concentrating and larger sorptive capacity. At violation of natural vegetation acid hydrolysis of a silicate and organic material, photochemical degradation of humus acids of soils go more intensively, organic matters collapse, the share of fulvic acids increases, the erosion that leads to carrying out of metals from soils in solution and with fine-grained particles develops. In agro landscapes the negative balance of biofilny elements $(\mathrm{P}, \mathrm{Mn})$ can be formed at the expense of carrying out with a crop. 
Table 1. The comparison of the dynamics of the chemical elements average grades in the soils of biogenic and technogenic landscapes of Krasnodar region

\begin{tabular}{|c|c|c|c|c|c|c|c|c|c|c|c|c|c|}
\hline \multirow{2}{*}{$\begin{array}{c}\text { Name } \\
\text { landscapes }\end{array}$} & \multirow{2}{*}{$\begin{array}{c}\text { Period } \\
\text { approba-tions }\end{array}$} & \multicolumn{12}{|c|}{ The elements maintenance $\left(\mathrm{n} * 10^{-3} \%\right)$} \\
\hline & & Mn & $\mathrm{Ni}$ & $\mathrm{Cu}$ & $\mathrm{Ti}$ & $\mathrm{V}$ & $\mathrm{Cr}$ & $\mathrm{Zn}$ & $\mathrm{Pb}$ & Co & Mo & $\mathrm{Ba}$ & $\mathrm{Ga}$ \\
\hline \multirow{2}{*}{$\begin{array}{c}\text { Biogenic } \\
\text { landscapes }\end{array}$} & $1980-1982$ & 121 & 5.7 & 4.7 & 637 & 15.9 & 9.9 & 15.3 & 2.2 & 2.2 & 0.46 & 109 & 2.14 \\
\hline & 1993-1995 & 138 & 5.9 & 5.5 & 605 & 15.9 & 14.3 & 14.6 & 3.2 & 2.2 & 0.32 & 83 & 2.03 \\
\hline \multirow{2}{*}{$\begin{array}{l}\text { Technogen } \\
\text { ic } \\
\text { landscapes }\end{array}$} & 1980-1982 & 84 & 4.5 & 6.1 & 533 & 14.3 & 10.4 & 12.6 & 3.3 & 1.9 & 0.48 & 73 & 1.95 \\
\hline & $1993-1995$ & 99 & 5.5 & 6.7 & 482 & 13.2 & 11.1 & 12.4 & 4.0 & 2.2 & 0.35 & 72 & 1.87 \\
\hline
\end{tabular}

Table 2. The average concentration of chemical elements $\left(\mathrm{n} * 10^{-3} \%\right)$ in soils of agricultural landscapes of the Volgodonsk region of the Rostov region during the various periods of approbation (the top line - 1981, the bottom line -1992)

\begin{tabular}{|c|c|c|c|c|c|c|c|c|c|c|c|c|c|c|c|}
\hline $\mathrm{Cu}$ & $\mathrm{Zn}$ & $\mathrm{Pb}$ & $\mathrm{Ag}$ & $\mathrm{Sn}$ & Mo & $\mathrm{Ba}$ & Co & $\mathrm{Ni}$ & $\mathrm{Mn}$ & $\mathrm{Ti}$ & V & $\mathrm{Cr}$ & $\mathrm{Ga}$ & $\mathrm{P}$ & $\mathrm{Li}$ \\
\hline \multicolumn{16}{|c|}{ Pastures on steppes, transaccumulative } \\
\hline 6.2 & 11.2 & 4.9 & 0.007 & 0.53 & 0.24 & 104 & 2.1 & 4.3 & 106 & 514 & 8.5 & 9.7 & 1.9 & 116 & 5.6 \\
\hline 7.2 & 10.1 & 5.7 & 0.011 & 0.51 & 0.32 & 95 & 2.1 & 5.1 & 87 & 475 & 11.2 & 11.2 & 2.0 & 82 & 6.0 \\
\hline \multicolumn{16}{|c|}{ Field one-year, bogarny, eluvial } \\
\hline 6.9 & 11.4 & 4.6 & 0.007 & 0.44 & 0.21 & 106 & 2.3 & 4.2 & 139 & 611 & 8.9 & 10.1 & 1.7 & 125 & 6.2 \\
\hline 6.6 & 8.9 & 5.5 & 0.009 & 0.49 & 0.59 & 106 & 2.0 & 4.9 & 87 & 495 & 10.7 & 10.7 & 1.9 & 71 & 5.9 \\
\hline \multicolumn{16}{|c|}{ Field one-year, bogarny, transeluvial } \\
\hline 5.7 & 9.9 & 4.6 & 0.007 & 0.49 & 0.24 & 103 & 2.2 & 4.2 & 91 & 499 & 8.9 & 9.8 & 1.8 & 121 & 5.4 \\
\hline 6.7 & 9.1 & 5.6 & 0.009 & 0.50 & 0.44 & 101 & 2.1 & 5.1 & 91 & 492 & 10.6 & 11.5 & 1.9 & 78 & 5.9 \\
\hline \multicolumn{16}{|c|}{ Field one-year, bogarny, transaccumulative } \\
\hline 5.7 & 10.9 & 4.3 & 0.007 & 0.51 & 0.24 & 115 & 2.1 & 4.4 & 99 & 532 & 8.7 & 9.8 & 1.8 & 119 & 6.3 \\
\hline 7.2 & 10.4 & 5.5 & 0.010 & 0.51 & 0.30 & 87 & 2.0 & 5.5 & 95 & 512 & 10.6 & 13.1 & 2.0 & 87 & 6.0 \\
\hline \multicolumn{16}{|c|}{ Field one-year, raflux, transaccumulative } \\
\hline 7.4 & 10.6 & 5.6 & 0.007 & 0.48 & 0.28 & 115 & 2.3 & 4.5 & 102 & 558 & 9.3 & 10.3 & 1.8 & 150 & 5.8 \\
\hline 6.4 & 8.7 & 5.7 & 0.012 & 0.50 & 0.30 & 95 & 2.1 & 5.0 & 88 & 483 & 11.7 & 12.5 & 2.0 & 77 & 6.0 \\
\hline
\end{tabular}

Table 3. Dynamics of average concentration of chemical elements in soils of meadow pastures of a flood plain and the Don River (Rostov region) delta

\begin{tabular}{|c|c|c|c|c|c|c|c|c|c|c|}
\hline \multirow{2}{*}{$\begin{array}{c}\text { Name } \\
\text { landscapes }\end{array}$} & \multirow{2}{*}{$\begin{array}{c}\text { Period } \\
\text { approbations }\end{array}$} & \multicolumn{9}{|c|}{ Maintenance of elements $\left(\mathrm{n} * 10^{-3} \%\right)$} \\
\hline & & $\mathrm{Mn}$ & $\mathrm{Ni}$ & $\mathrm{Cu}$ & $\mathrm{Ti}$ & V & $\mathrm{Cr}$ & $\mathrm{Zn}$ & $\mathrm{Pb}$ & Co \\
\hline \multirow{2}{*}{$\begin{array}{l}\text { The inundated } \\
\text { landscapes }\end{array}$} & $1977-1982$ & 55.7 & 3.7 & 3.6 & 400 & 13.7 & 10.9 & 6.1 & 1.9 & 1.4 \\
\hline & $1995-2000$ & 71.9 & 5.2 & 3.9 & 409 & 10.8 & 26.1 & 9.6 & 2.2 & 1.7 \\
\hline \multirow{2}{*}{$\begin{array}{l}\text { The deltoid } \\
\text { landscapes }\end{array}$} & $1977-1981$ & 45.5 & 3.3 & 3.4 & 380 & 8.6 & 10.5 & 4.6 & 2.1 & 1.2 \\
\hline & $1995-2000$ & 64.7 & 4.6 & 3.6 & 458 & 10.2 & 29.8 & 8.2 & 2.4 & 1.3 \\
\hline
\end{tabular}

Table 4. Dynamics of average concentration of chemical elements in soils of North Ossetia $\left(\mathrm{n} * 10^{-3} \%\right)$

\begin{tabular}{|c|c|c|c|c|c|c|c|c|c|c|c|c|c|}
\hline $\mathrm{Mn}$ & $\mathrm{Ni}$ & $\mathrm{Cu}$ & $\mathrm{V}$ & $\mathrm{Cr}$ & $\mathrm{Zn}$ & $\mathrm{Pb}$ & Co & Mo & $\mathrm{Ba}$ & $\mathrm{Ag}$ & $\mathrm{Sr}$ & $\mathrm{Sn}$ & $\mathrm{Be}$ \\
\hline \multicolumn{14}{|c|}{ Brown soils of North Ossetia by data [2] } \\
\hline 160 & 1.6 & 2.3 & 5.5 & 7.1 & 5.6 & 4.2 & $<1$ & 0.15 & 59 & $<0.01$ & $<10$ & 0.1 & 0.1 \\
\hline \multicolumn{14}{|c|}{ Brown soils of North Ossetia in $1988 \mathrm{~g}$ according to Dyachenko V. V } \\
\hline 125 & 4.6 & 3.9 & 13.6 & 9.9 & 14.9 & 4.7 & 2.2 & 0.32 & 65 & 0.0146 & 16 & 0.65 & 0.35 \\
\hline \multicolumn{14}{|c|}{ The average contents in soils of North Ossetia [2] } \\
\hline 164 & 2.2 & 2.6 & 9.2 & 9.0 & 8.3 & 3.4 & $<1$ & 0.15 & 61 & $<0.01$ & $<10$ & 0.1 & 0.1 \\
\hline \multicolumn{14}{|c|}{ The average contents in soils of the North Caucasus [3] } \\
\hline 93 & 4.7 & 5.1 & 12.6 & 11.0 & 10.6 & 3.5 & 2.0 & 0.31 & 72 & 0.010 & 22 & 0.56 & 0.39 \\
\hline
\end{tabular}




\subsection{Calculation and Assessment of Regional Clark of Soils and Rocks}

As a whole environmental is the universal problem and is reflected even in such global sizes as clark of soils. If the clark calculated by various authors to arrange on time of their definition: A.P.Vinogradov - the 40-50th years, A.Kabata-Pendias - the 60-70th, H.Shaklett and J. Borngem (soil of the USA) - the 70th, A.B.Ronov and A.A.Yaroshevsky - the 70-80th, V. V. Dyachenko (soil of the North Caucasus) - the 80-90th years, is found out that concentration of the majority of elements with a high technophiles increase ( 15 of 25 considered) and many is almost serial - $\mathrm{Zn}, \mathrm{Cu}, \mathrm{Pb}, \mathrm{Ba}, \mathrm{Co}$, Sc, etc. (Table 5).

Uniform and large volume of approbation (for calculation 5314 tests of soils are used), within large biospheric structure what the North Caucasus (area more than 300000 $\mathrm{km}^{2}$ ) is allow to consider these data rather objective and comparable on scales. And so, in soils of the North Caucasus (the last, on approbation time) concentration of $\mathrm{Cu}, \mathrm{Zn}, \mathrm{Pb}, \mathrm{Mo}, \mathrm{W}$, Co, Ni in 1,5-3 times above, sizes taken for comparison. To a lesser extent they are enriched with $\mathrm{Ba}$, $\mathrm{Ge}, \mathrm{Mn}, \mathrm{Ti}, \mathrm{V}, \mathrm{Li}, \mathrm{Sn}, \mathrm{Cr}, \mathrm{Sc}, \mathrm{Be}$. It means that deviations of regional clark of soils of the North Caucasus from the world can be a consequence of development of global processes connected with technogenesis, cross-border transfer, biosphere "metallization" in the last decades. Pays attention that among the elements which are most enriching soils of the Caucasus, there are $\mathrm{Cu}, \mathrm{Zn}, \mathrm{Pb}, \mathrm{Mo}, \mathrm{W}$ being the main ore minerals. And $\mathrm{Cu}$ and Mo, besides, are a part of many chemicals which are applying in agriculture. For all listed elements excess of ecological standards for concentration level in soils of the region [9] is characteristic also. All this can testify to metallogenic and technogenic specifics of the North Caucasus.

Table 5. Comparison of the average concentration of chemical elements in soils The North Caucasus with clark of soils of the world and certain territories $\left(\% \mathrm{n}^{*} 10^{-3}\right)$

\begin{tabular}{|c|c|c|c|c|c|}
\hline \multirow[b]{2}{*}{ Element } & \multicolumn{5}{|c|}{ Clark of soils } \\
\hline & $\begin{array}{l}\text { Vinogradov, } \\
1957\end{array}$ & $\begin{array}{l}\text { Kabata-Pendias, Pendias, } \\
1979\end{array}$ & $\begin{array}{c}\text { Shaklett, Borngem, } \\
1984\end{array}$ & $\begin{array}{c}\text { Ronov and } \\
\text { Yaroshevsky, } \\
1990 \\
\end{array}$ & $\begin{array}{l}\text { Soils of the North } \\
\text { Caucasus }\end{array}$ \\
\hline $\mathrm{Ti}$ & 460.0 & 350.0 & 290.0 & 370.0 & $503.0 \pm 3.0$ \\
\hline $\mathrm{Mn}$ & 85.0 & 54.0 & 55.0 & 50.0 & $93.0 \pm 1.0$ \\
\hline $\mathrm{P}$ & 80.0 & 70.0 & - & 80.0 & $89.0 \pm 1.0$ \\
\hline $\mathrm{Ba}$ & 50.0 & $21.0-63.0$ & 58.0 & 50.0 & $72.0 \pm 1.0$ \\
\hline $\mathrm{Sr}$ & 30.0 & $12.0-68.0$ & 24.0 & 22.0 & $21.6 \pm 0.4$ \\
\hline $\mathrm{Zr}$ & 30.0 & $13.0-35.0$ & 23.0 & 30.0 & $17.1 \pm 0.2$ \\
\hline $\mathrm{Cr}$ & 20.0 & 6.5 & 5.4 & 6.0 & $10.9 \pm 0.1$ \\
\hline V & 10.0 & 9.0 & 8.0 & 9.0 & $12.6 \pm 0.1$ \\
\hline $\mathrm{Zn}$ & 5.0 & 6.0 & 6.0 & 6.0 & $10.6 \pm 0.1$ \\
\hline Y & 5.0 & $1.0-2.2$ & 2.5 & 2.5 & $1.98 \pm 0.02$ \\
\hline $\mathrm{Ni}$ & 4.0 & 2.0 & 1.9 & 2.0 & $4.7 \pm 0.04$ \\
\hline $\mathrm{Ga}$ & 3.0 & 2.8 & 1.7 & 2.0 & $1.86 \pm 0.01$ \\
\hline $\mathrm{Li}$ & 3.0 & $3.1-7.3$ & 2.4 & 3.0 & $5.55 \pm 0.03$ \\
\hline $\mathrm{Cu}$ & 2.0 & $2.0-3.0$ & 2.5 & 2.3 & $5.1 \pm 0.1$ \\
\hline $\mathrm{Pb}$ & 1.0 & 2.5 & 1.9 & 2.0 & $3.5 \pm 0.04$ \\
\hline $\mathrm{Nb}$ & - & 2.4 & 1.1 & 1.1 & $1.81 \pm 0.02$ \\
\hline $\mathrm{Sn}$ & 1.0 & 0.45 & 0.13 & 0.11 & $0.56 \pm 0.004$ \\
\hline Co & 0.8 & 0.85 & 0.91 & 0.9 & $2.01 \pm 0.02$ \\
\hline $\mathrm{Sc}$ & 0.7 & $0.15-1.25$ & 0.89 & 0.8 & $0.96 \pm 0.01$ \\
\hline $\mathrm{Be}$ & 0.6 & $0.035-0.27$ & 0.16 & 0.15 & $0.39 \pm 0.004$ \\
\hline Mo & 0.2 & 0.2 & 0.097 & 0.2 & $0.31 \pm 0.01$ \\
\hline $\mathrm{Ge}$ & $0 . n$ & - & 0.12 & 0.13 & $0.21 \pm 0.002$ \\
\hline $\mathrm{Yb}$ & 0.033 & $0.23-0.31$ & 0.31 & 0.3 & $0.25 \pm 0.002$ \\
\hline W & - & $0.07-0.27$ & $0.12-0.25$ & 0.1 & $0.22 \pm 0.003$ \\
\hline $\mathrm{Ag}$ & $0.0 \mathrm{n}$ & $0.005-0.01$ & 0.07 & 0.01 & $0.01 \pm 0.0001$ \\
\hline
\end{tabular}


The Trace Elements Concentrations Dynamics in the Soil Landscapes of the Southern Russia

Table 6. Comparison of regional clark of rocks The North Caucasus with litosphere clark $\left(\% \mathrm{n} * 10^{-3}\right)$

\begin{tabular}{|c|c|c|c|c|c|}
\hline \multirow[b]{2}{*}{ Element } & \multicolumn{5}{|c|}{ Clark of a litosphere } \\
\hline & $\begin{array}{c}\text { Taylor, } \\
1964 \\
\end{array}$ & Vinogradov, 1967 & $\begin{array}{l}\text { Beus, } \\
1974\end{array}$ & $\begin{array}{l}\text { Ronov and Yaroshevsky, } \\
1990\end{array}$ & $\begin{array}{c}\text { Rocks } \\
\text { North Caucasus } \\
\end{array}$ \\
\hline $\mathrm{Ti}$ & 570 & 450 & 330 & 320 & $366 \pm 6$ \\
\hline$P$ & 105 & 93 & 80 & 70 & $60 \pm 1$ \\
\hline $\mathrm{Mn}$ & 95 & 100 & 70 & 77 & $73 \pm 2$ \\
\hline $\mathrm{Ba}$ & 42.5 & 65 & 68 & 58 & $52 \pm 1$ \\
\hline $\mathrm{Sr}$ & 37.5 & 34 & 23 & 29 & $30 \pm 1$ \\
\hline $\mathrm{Zr}$ & 16.5 & 17 & 17 & 17 & $12.5 \pm 0.3$ \\
\hline V & 13.5 & 9 & 7.6 & 11 & $8.8 \pm 0.2$ \\
\hline $\mathrm{Cr}$ & 10.0 & 8.3 & 3.4 & 9.9 & $8.8 \pm 0.3$ \\
\hline $\mathrm{Ni}$ & 7.5 & 5.8 & 2.6 & 5.8 & $3.1 \pm 0.1$ \\
\hline $\mathrm{Zn}$ & 7.0 & 8.3 & 5.1 & 7.6 & $6.9 \pm 0.2$ \\
\hline $\mathrm{Cu}$ & 5.5 & 4.7 & 2.2 & 4.6 & $3.7 \pm 0.1$ \\
\hline $\mathrm{Y}$ & 3.3 & 2.0 & 3.6 & 2.8 & $1.5 \pm 0.03$ \\
\hline Co & 2.5 & 1.8 & 0.7 & 2.3 & $121 \pm 0.04$ \\
\hline $\mathrm{Sc}$ & 2.2 & 1.0 & 1.1 & 1.6 & $0.7 \pm 0.01$ \\
\hline $\mathrm{Li}$ & 2.0 & 3.2 & 3.0 & 2.7 & $4.01 \pm 0.07$ \\
\hline $\mathrm{Nb}$ & 2.0 & 2.0 & 2.0 & 1.6 & $1.26 \pm 0.03$ \\
\hline $\mathrm{Ga}$ & 1.5 & 1.9 & 1.9 & 1.9 & $1.38 \pm 0.03$ \\
\hline $\mathrm{Pb}$ & 1.25 & 1.6 & 1.6 & 1.6 & $2.6 \pm 0.1$ \\
\hline $\mathrm{Be}$ & 0.28 & 0.38 & 0.25 & 0.35 & $0.27 \pm 0.04$ \\
\hline $\mathrm{Sn}$ & 0.2 & 0.25 & 0.27 & 0.25 & $0.3 \pm 0.01$ \\
\hline W & 0.15 & 0.13 & 0.19 & 0.12 & $0.18 \pm 0.004$ \\
\hline $\mathrm{Ge}$ & 0.15 & 0.14 & 0.13 & 0.15 & $0.15 \pm 0.004$ \\
\hline Mo & 0.15 & 0.11 & 0.13 & 0.1 & $0.25 \pm 0.01$ \\
\hline $\mathrm{Yb}$ & 0.03 & 0.033 & 0.36 & 0.30 & $0.17 \pm 0.004$ \\
\hline $\mathrm{Ag}$ & 0.007 & 0.007 & 0.005 & 0.007 & $0.0066 \pm 0.0002$ \\
\hline
\end{tabular}

For the objective analysis of regional clark of soils of the North Caucasus we will consider rocks. It is thus important to note that among authors of clark of a litosphere there are also authors of clark of soils - A.P.Vinogradov and A.B.Ronov with A.A.Yaroshevsky. Comparison with these data (Table 6) testifies that regional clark of rocks of the North Caucasus (for calculation 2335 tests are used) in most cases are in an interval formed by clark of various authors.

It emphasizes objectivity of the conclusions concerning both rocks, and soils of the North Caucasus which analysis was made at the same devices, at the same time. At some convention of such comparison caused by essential divergences in clarks of different authors, many features of distribution of chemical elements in soils coincide with rocks.
For example, soils, as well as rocks, are enriched with $\mathrm{Sn}, \mathrm{W}$, $\mathrm{Pb}, \mathrm{Li}, \mathrm{Ti}$ and are grown poor by $\mathrm{Ga}, \mathrm{Y}, \mathrm{Yb}, \mathrm{Zr}$. In both cases the close to clark values have Ag, Sr, P.

As a whole, rocks of the North Caucasus are grown poor by chemical elements (only - Mo, Sn, Pb, W, Li and Ti exceed clark), and soils are mainly enriched (only - $\mathrm{Ga}, \mathrm{Yb}$, $\mathrm{Y}, \mathrm{Zr}$ below clark). The most bright deviations are characteristic for $\mathrm{Ni}, \mathrm{Co}, \mathrm{Sc}, \mathrm{Cr}, \mathrm{V}, \mathrm{Mn}, \mathrm{Cu}, \mathrm{Zn}$. It is easy to notice that mostly it is elements of group of iron, concentrating in averages and the main breeds. The analysis of history of development of the region allows to make the assumption of possible influence of volcanic activity [3].Other factor of transformation of clark ratios of chemical elements is ore specifics of the region and the accompanying 
environmental which is forming at investigation, production and mineral processing. These factors have especially great impact on $\mathrm{W}$ redistribution, $\mathrm{Mo}, \mathrm{Sn}, \mathrm{Cu}, \mathrm{Zn}, \mathrm{Pb}, \mathrm{Ag}$ and others, being with them in a paragenesis or accompanying chemical elements. The recorded geochemical anomalies occupy hundreds square kilometers that led to increase of a regional hum noise of many microcells.

Studying of distribution of chemical elements in soils with intensive agricultural technologies gives some assumptions of the nature of a geochemical originality of landscapes of the region. They considerably transform a natural geochemical range of soils [3]. On the basis of their comparison to soils of natural landscapes it is possible to construct ranks of enrichment or impoverishment of soils as a result of agricultural activity.

Soils of agro landscapes with intensive technologies in comparison with a regional hum noise are enriched -

$\mathrm{Cu}$ and $\mathrm{Ni}$ (by 1,3 times) $>\mathrm{Mo}, \mathrm{P}$ and $\mathrm{V}(1,2)>\mathrm{Cr}, \mathrm{Zn}, \mathrm{W}$ and Co $(1,1)$;

are grown poor -

Mn (by 1,3 times) $>\operatorname{Be}(1,2)>\operatorname{Sr}(1,1)$.

Proceeding from the analysis of these ranks the raised maintenance of $\mathrm{Cu}, \mathrm{Ni}, \mathrm{Zn}, \mathrm{Mo}, \mathrm{P}, \mathrm{V}, \mathrm{W}, \mathrm{Co}, \mathrm{Cr}$ and the under $\mathrm{Sr}$ in soils of the North Caucasus in comparison with clark can be caused by geochemical specifics of the types of environmental management developed here and pollution both technogenic and boundary natural landscapes.

In favor of the technogenic nature of increase of concentration of microcells in soils of the region monitoring of soils of the cities, industrial facilities of the South of Russia and comparison with soils of environmental landscapes $[3,11,12]$ testifies. As a result of these studies it is revealed essential (1,3-1,5 times) increase of concentration of microcells in soils of settlements in 8-12 years of intensive industrial development at a turn of centuries. And, with an approximation to the production enterprises not only concentration of chemical elements in soils increase, but also health of people living here worsens. Extent of pollution of the cities and adjacent landscapes is defined by specifics of technogenic loading, a saturation industrial facilities, and also the sizes of settlements. Most often as a part of pollution there are $\mathrm{Cr}, \mathrm{Ni}, \mathrm{Pb}, \mathrm{Ag}, \mathrm{Cu}, \mathrm{Zn}, \mathrm{P}, \mathrm{Mn}, \mathrm{Sn}$.

\subsection{Assessment of the Modern Dynamics of Trace Elements in Soils of the South of Russia}

For an assessment of the modern dynamics of trace elements we use results of approbation of soils of flat part of the South of Russia in 2010-2012 (824 tests). Having allocated from a database the North Caucasus tests of 1989-1998 taken in flat part (4332 samples), we will compare them to the modern contents (Table 7).

These selections are not quite identical. The samples of the Voronezh, Krasnodar and Stavropol regions were included in the first group. In the second group was included the samples not only from these regions, but also from Kalmykia, Astrakhan and Volgograd regions. It affected increase of average maintenance of $\mathrm{Ti}, \mathrm{P}$ and decrease $\mathrm{Ba}$ [13]. Nevertheless, it is apparent that the tendencies revealed on the basis of studying of dynamics of trace elements at the end of the last century, remain. From 19 considered trace elements concentration 12 increase, and decrease only 5 . And, essential decrease in concentration is noted only for one chemical element - Ba. Generally the list of trace elements remains also.

Table 7. Comparison of the average concentration of chemical elements in soils of flat part of the South of Russia during the different periods of approbation (with probability $95 \%$ )

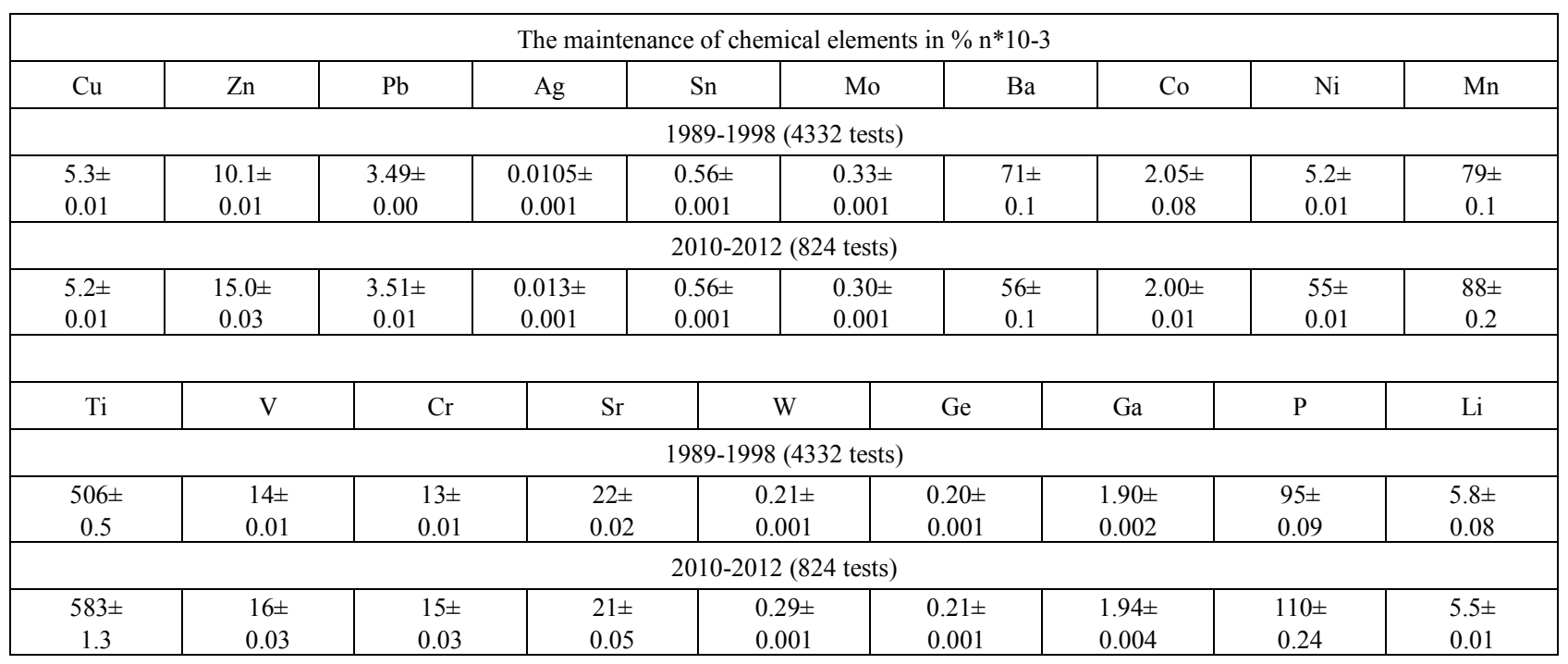




\section{Conclusions}

Generalizing results of studying of the trace elements dynamics in soils of the South of Russia them it is possible to unite in some groups. The first group microcells with intensive increase in concentration in all regions - $\mathrm{Cr}$ form, $\mathrm{Ni}, \mathrm{Pb}, \mathrm{Ag}, \mathrm{W}$. To them it is conditionally possible to add $\mathrm{Sr}$, but it is considered only in a pollution zone. Increase of concentration of elements of the second group less intensively and unambiguously - V, Cu, Be, Sn, Ge. The third group includes elements with poorly expressed, but counter dynamics - Ti, P, Ba. The fourth group microcells with very contrast and ambiguous redistribution in various landscape and geochemical conditions of the region - Mn form, $\mathrm{Zn}, \mathrm{Mo}$. At last, the fifth group trace elements with not only ambiguous, but also very weak dynamics - Li form, Ga, Co.

Thus, the analysis of dynamics of trace elements in soils of the South of Russia testifies in various intensity and an orientation of the chemical elements concentration change, but for the majority accumulation in region soils that leads to pollution and biosphere "metallization" is characteristic. Results of comparison of regional clark of soils and rocks of the North Caucasus with the world confirm their reliability and an originality regarding the increased concentration of many chemical elements and positive dynamics in soils in the last decades. All given materials testify that body height of concentration and change of ratios of chemical elements, though reflects interaction of many factors accompanying region development, but anthropogenesis has decisive influence on dynamics of microcells in soils.

\section{Acknowledgements}

Work was supported by the RFBR (grant 13-05-96514).

\section{REFERENCES}

[1] Vinogradov A.P.Geokhimiya of infrequent and dispelled chemical elements in soils, Moscow, 157, 1957.

[2] Rubilin E.V. Trace elements in soils of the North Caucasus, Leningrad, 56, 1968.

[3] Dyachenko V. V. Geochemistry, systematics and assessment of a condition of landscapes of the North Caucasus, Rostov-on-Don, Publishing center "Kompleks", 268, 2004.

[4] Yevseyev A.V. Time histories of background concentration of pollutants in various natural objects/ The Messenger of the Moscow State University. It is gray. Geogr., No. 4, 35-46,1988.

[5] Kabata-Pendias A., Pendias H., Trace Elements in the Biological Environment, Wyd. Geol., Warsaw, 300, 1979.

[6] Sadovnikova L.K. Heavy metals//Soil environmental monitoring and protection of soils, Moscow State University publishing house, Moscow, 105-126, 1994.

[7] Ronov A.B. Yaroshevsky A.A. Migdisov A.A. Chemical constitution of crust and geochemical balance of the main elements , Nauka, Moscow, 182, 1990.

[8] Shacklette H. T., Boerngen J. G., Element concentration in soils and other surficial materials of the conterminous United States, U.S. Geol Surv Prof. Pap., 1270, 1984.

[9] Dyachenko V. V., Berg of Yu. Danilov S. V. Environmental monitoring and rationing of metals in soils. The Vector of science Tolyatti state university. Vyp No. 2 (16). Tolyatti, 38-42, 2011.

[10] Taylor S.R. Abundance of chemical elements in the continental crust a new table, Geochim. Cosmochim. Acta, vol. 28, 1273-1285, 1964.

[11] Dyachenko V. V., Matasova I.Yu. Rogovsky V.V.Problemy of technogenic transformation of landscapes of the Russian Black Sea Coast. Safety in a technosphere, Moscow, No. 5, 30-36, 2012.

[12] Malykhin Yu. A., Malykhina A. G., Dyachenko V. V. Medico-ecological researches urbanized by Territories. Safety in a technosphere, No. 3, 16-21, 2008.

[13] Dyachenko V. V., Matasova I.Yu. The background concentration of chemical elements in soils of physiographic areas of the South of Russia. Problems of regional ecology, Moscow, No. 4, 148-154, 2012. 